\title{
Peningkatan Hasil Belajar Kognitif Siswa Menggunakan Model Pembelajaran Kooperatif Tipe Group Investigation
}

\author{
${ }^{1}$ Dian Esti Pertiwi, ${ }^{2}$ Taufik Samsuri, ${ }^{* 3}$ Agus Muliadi \\ 1,2\&3Program Studi Pendidikan Biologi, FPMIPA, IKIP Mataram, Jl. Pemuda No. \\ 59A Mataram, Indonesia 83125 \\ Email:agusmuliadi@ikipmataram.ac.id
}

\begin{tabular}{|c|c|}
\hline ARTICLE INFO & ABSTRACT \\
\hline $\begin{array}{l}\text { Article history } \\
\text { Received: March } 2019 \\
\text { Revised: April } 2019 \\
\text { Accepted: May } 2019 \\
\text { Published: June } 2019 \\
\text { Keywords } \\
\text { Cooperative learning model; } \\
\text { Group investigation; } \\
\text { Cognitive learning outcomes }\end{array}$ & $\begin{array}{l}\text { [Title: Improving Student Cognitive Learning Outcomes using Cooperative } \\
\text { Learning Model Type Group Investigation]. The purpose of this study was to } \\
\text { improve student cognitive learning outcomes using the Cooperative Learning Model } \\
\text { Type Group Investigation in class X MIA } 2 \text { students of SMAS NW Mataram in the } \\
2018 / 2019 \text { academic year. The subjects of this study were } 15 \text { students of class X MIA } \\
\text { 2. This research is a classroom action research (CAR) consisting of two cycles. } \\
\text { Observation sheet of learning implementation is used for each meeting to find out the } \\
\text { implementation of learning steps according to the learning implementation plan } \\
\text { observed by } 2 \text { observers. Test instruments of } 20 \text { multiple choice questions and } 5 \\
\text { description questions were used in this study to find out the improvement of students' } \\
\text { cognitive learning outcomes in each cycle. The results showed the implementation of } \\
\text { learning in the cycle I (1) the first meeting reached } 63.63 \% \text { with a good category and } \\
\text { the second meeting reached } 88.8 \% \text { with a very good category, (2) the cognitive learning } \\
\text { outcomes of students in cycle } 1 \text { obtained an average value } 59 \text { with the classical } \\
\text { completeness value achieved } 46 \% \text { of the incomplete category, while in cycle II (3) the } \\
\text { first meeting of the implementation of learning reached } 72.72 \% \text { with a good category } \\
\text { (4) the second meeting reached } 94.44 \% \text { with a very good category, and for results } \\
\text { cognitive learning students obtained an average value of } 72 \text { with a classical } \\
\text { completeness value achieved } 76 \% \text {. Based on the results of the study it can be concluded } \\
\text { that the Cooperative Learning Model Type Group Investigation can improve cognitive } \\
\text { learning outcomes of class XMIA } 2 \text { students of SMAS NWMataram in the } 2018 / 2019 \\
\text { academic year. }\end{array}$ \\
\hline
\end{tabular}

\begin{tabular}{|c|c|}
\hline INFO ARTIKEL & ABSTRAK \\
\hline $\begin{array}{l}\text { Sejarah Artikel } \\
\text { Dikirim: Maret } 2019 \\
\text { Direvisi: April } 2019 \\
\text { Diterima: Mei } 2019 \\
\text { Dipublikasi: Juni } 2019 \\
\text { Kata kunci } \\
\text { Model pembelajaran } \\
\text { kooperatif; } \\
\text { Group investigation; } \\
\text { Hasil belajar kognitif }\end{array}$ & $\begin{array}{l}\text { Tujuan penelitian ini adalah untuk meningkatkan hasil belajar kognitif siswa } \\
\text { menggunakan model pembelajaran Kooperatif Tipe Group Investigation pada } \\
\text { siswa kelas X MIA } 2 \text { SMAS NW Mataram Tahun Pelajaran 2018/2019. Subjek } \\
\text { penelitian ini adalah } 15 \text { siswa kelas X MIA } 2 \text {. Penelitian ini merupakan } \\
\text { penelitian tindakan kelas (PTK) yang terdiri dari dua siklus. Lembar observasi } \\
\text { keterlaksanaan pembelajaran digunakan untuk pada setiap pertemuan untuk } \\
\text { mengetahui keterlaksanaan langkah-langkah pembelajaran sesuai rencana } \\
\text { pelaksanaan pembelajaran yang diamati oleh } 2 \text { observer. Instrumen tes } \\
\text { sebanyak } 20 \text { item soal pilihan ganda dan } 5 \text { soal uraian digunakan dalam } \\
\text { penelitian ini untuk mengetahui peningkatan hasil belajar kognitif siswa pada } \\
\text { setiap siklus. Hasil penelitian menunjukkan keterlaksanaan pembelajaran pada } \\
\text { siklus I (1) pertemuan pertama mencapai } 63,63 \% \text { dengan kategori baik dan } \\
\text { pada pertemuan kedua mencapai } 88,8 \% \text { dengan kategori sangat baik, (2) hasil }\end{array}$ \\
\hline
\end{tabular}


belajar kognitif siswa pada siklus 1 diperoleh nilai rata-rata 59 dengan nilai ketuntasan klasikal yang dicapai $46 \%$ kategori tidak tuntas, sedangkan pada siklus II (3) pertemuan pertama keterlaksanaan pembelajaran mencapai 72,72\% dengan kategori baik (4) pertemuan kedua mencapai 94,44\% dengan kategori sangat baik, dan untuk hasil belajar kognitif siswa diperoleh nilai rata-rata 72 dengan nilai ketuntasan klasikal yang dicapai 76\%. Berdasarkan hasil penelitian dapat disimpulkan bahwa model pembelajaran kooperatif tipe Group Investigation dapat meningkatkan hasil belajar kognitif siswa kelas X MIA 2 SMAS NW Mataram Tahun Pelajaran 2018/2019.

How to Cite this Article? Pertiwi, D., E., Samsuri, T., \& Muliadi, A. (2019). Peningkatan Hasil Belajar Kognitif Siswa Menggunakan Model Pembelajaran Kooperatif Tipe Group Investigation. Jurnal Penelitian dan Pengkajian Ilmu Pendidikan: e-Saintika, 2(2), 135-141.

\section{PENDAHULUAN}

Belajar merupakan aktivitas yang tidak pernah terpisahkan dalam kehidupan manusia yang tidak hanya melibatkan penguasaan suatu kemampuan atau masalah akademik, tetapi juga berkaitan dengan perkembangan emosi, interaksi sosial, dan perkembangan kepribadian sosial, yang mana proses belajar ini terjadi di dalam diri individu yang berinteraksi dengan lingkungan untuk mendapatkan perubahan dalam perilakunya (Sanjaya, 2009). Hasil belajar siswa dapat dipengaruhi oleh dua faktor utama yaitu faktor internal (psikologi dan fisik) dan faktor eksternal (faktor yang berasal dari luar diri siswa). Salah satu faktor dari luar diri siswa adalah pengaruh lingkungan sekitar dan juga model yang digunakan guru dalam menyampaikan materi (Ama \& Sartati, 2018; Pour dkk., 2018). Penerapan model pembelajaran yang sesuai mempengaruhi keberhasilan siswa dalam memahami materi pelajaran, mencapai keterampilan proses sains dan meningkatkan hasil belajar (Primarinda, 2012).

Hasil belajar kognitif adalah perilaku yang terjadi dalam kawasan kognisi. Proses belajar yang melibatkan kognisi meliputi kegiatan sejak dari penerimaan stimulus eksternal oleh sensori, penyimpanan dan pengolahan dalam otak menjadi informasi hingga pemanggilan kembali informasi ketika diperlukan untuk menyelesaikan masalah. Hasil belajar kognitif merupakan perubahan perilaku yang terjadi dalam lingkup kognisi yang tidak hanya membahas kemampuan tunggal melainkan kemampuan yang menimbulkan perubahan perilaku dalam domain kognitif yang memiliki beberapa jenjang yang terdiri dari dari, $\mathrm{C}_{1}$-mengingat, $\mathrm{C}_{2^{-}}$ memahami, $\mathrm{C}_{3}$-menerapkan, $\mathrm{C}_{4}$-menganalisis, $\mathrm{C}_{5}$-menilai, $\mathrm{C}_{6}$-berkreasi/mencipta (Anderson \& Krathwohl, 2001).

Pengembangan model-model pembelajaran merupakan salah satu cara yang harus dipersiapkan dan dilakukan oleh guru dalam kegiatan pembelajaran, dalam upaya meningkatkan hasil belajar siswa. Guru merupakan salah satu kunci keberhasilan kegiatan pembelajaran di sekolah yang terlibat langsung dalam merencanakan dan melaksanakan kegiatan pembelajaran. Kualitias kegiatan pembelajaran yang dilakukan sangat bergantung pada perencanaan dan pelaksanaan proses pembelajaran yang diterapkan oleh guru. Tugas guru tidak sekedar mengajar, tetapi lebih kepada membelajarkan siswa dengan berbagai pendekatan dan model pembelajaran. Sudjana (2010) menyatakan hasil belajar adalah kemampuan yang dimiliki siswa setelah menerima pengalaman belajar. Lebih lanjut Warsito (2012) mengemukakan bahwa hasil dari kegiatan belajar 
ditandai dengan adanya perubahan perilaku ke arah positif yang relatif permanen pada diri orang yang belajar.

Berdasarkan hasil wawancara dengan guru mata pelajaran Biologi kelas $X$ MIA SMAS NW Mataram diperoleh informasi bahwa hasil belajar kognitif sebagian besar siswa di kelas tersebut masih rendah (kurang memuaskan), hal ini dikarenakan guru masih lebih dominan menggunakan metode ceramah dengan alasan bahwa metode ceramah sampai kapanpun tidak akan pernah bisa terpisahkan dari proses pembelajaran. Hasil wawancara juga menunjukkan bahwa proses pembelajaran kooperatif juga pernah digunakan dalam proses pembelajaran, tetapi dalam pelaksanaannya belum maksimal karena sangat jarang diterapkan. Selain itu, kurangnya hasil belajar kognitif siswa ini diperkuat dengan penjelasan dari guru mata pelajaran bahwa tingkat keberhasilan hasil belajar kognitif sekitar $50 \%$, dari 15 orang siswa hanya 9 orang saja yang terkategori tuntas. Pencapaian tersebut tentu masih dibawa kriteria ketuntasan minimal (KKM) yaitu sebesar $75 \%$.

Berdasarkan hasil studi pendahuluan tersebut, sangat perlu dilakukan penelitian tentang pembelajaran koooperatif untuk meningkatkan hasil belajar kognitif siswa. Model pembelajaran koooperatif yang digunakan dalam penelitian ini adalah model pembelajaraan kooperatif tipe kelompok penyelidikan (group investigation). Penggunaan model kooperatif ini berusaha untuk mengaktifkan siswa dalam proses pembelajaran, yang kemudian bermuara pada tercapainya hasil belajar kognitif yang maksimal. Group investigation (GI) adalah sebagai salah satu model pembelajaran kooperatif yang menekankan pada proses pencarian pengetahuan dari pada transfer pengetahuan. Siswa dipandang sebagai subjek belajar yang perlu dilibatkan secara aktif dalam proses pembelajaran melalui berbagai aktivitas, dengan demikian, siswa diarahkan untuk menemukan sendiri berbagai fakta, membangun konsep, dan nilai-nilai baru yang diperlukan untuk kehidupannya (Primarinda, 2012). Hamdayama (2016) menyatakan bahwa GI adalah model yang melibatkan siswa sejak perencanaan, baik dalam menentukan topik maupun cara untuk mempelajarinya melalui investigasi dan juga untuk menuntut para siswa untuk memiliki kemampuan yang baik dalam berkomunikasi maupun dalam keterampilan proses kelompok.

GI banyak dikaji sebagai salah satu model pembelajaran inovatif, di antaranya adalah Sari dan Eurika (2016) menyatakan bahwa penerapan model pembelajaran GI dapat meningkatkan Hasil Belajar Siswa. Lebih lanjut Lubis dan Lubis (2017) menemukan bahwa penerapan model pembelajaran group dapat meningkatkan hasil belajar siswa. Sriwahyuningsih dkk (2018) menyatakan pembelajaran kooperatif tipe make a match dapat meningkatkan motivasi dan hasil belajar siswa. Sumiyati dkk (2017) menyatakan pembelajaran kooperatif tipe think pair share berpengaruh terhadap hasil belajar siswa. Berbeda dengan hasil penelitian tersebut, Khotimah dkk (2017) menyatakan bahwa pembelajaran kooperatif tipe listening team tidak berpengaruh signifikan terhadap hasil belajar siswa. Hasil penelitian empiris merekomendasikan agar penelitian menggunakan pembelajaran kooperatif dilaksanakan secara luas untuk mengetahui efektifitas pembelajaran secara komprehensif (Sriwahyuningsih dkk., 2018). Penelitian ini bertujuan untuk meningkatkan hasil belajar kognitif siswa menggunakan model pembelajaran 
kooperatif tipe group investigation pada siswa kelas X MIA 2 SMAS NW Mataram Tahun Pelajaran 2018/2019.

\section{METODE}

Jenis penelitian ini adalah Penelitian Tindakan Kelas (PTK) yang bertujuan untuk menyelesaikan permasalahan akademik di dalam kelas berdasarkan hasil refleksi diri (Sumadoyo, 2013) yang terdiri dari 4 tahapan, yaitu perencanaan, pelaksanaan, pengamatan, dan refleksi (Arikunto, 2012). Subyek dalam penelitian ini adalah siswa kelas X MIA 2 SMAS NW Mataram berjumlah 15 siswa. Instrumen berupa lembar observasi keterlaksanaan pembelajaran yang digunakan 2 observer pada setiap pertemuan pembelajaran, 20 item pilihan ganda, dan 5 item soal uraian digunakan dalam penelitian ini untuk mengetahui peningkatan hasil belajar kognitif siswa.

Data keterlaksanaan pembelajaran dan data hasil belajar kognitif dianalisis menggunakan rumus [Nilai $=$ (skor yang diperoleh/skor maksimum) $x 100]$, sedangkan ketuntasan klasikal $(\mathrm{KK})$ dianalisis menggunakan rumus $[K K=$ (jumlah siswa yang mendapatkan nilai $\geq 75 / j u m l a h$ siswa yang mengikuti evaluasi)x100\%] (Prayogi dkk., 2013). Penelitian ini dinyatakan berhasil jika keterlaksanaan pembelajaran dan hasil belajar kognitif siswa secara klasikal $\geq 75 \%$.

\section{HASIL DAN PEMBAHASAN}

Hasil penelitian ini meliputi data tentang keterlaksanaan pembelajaran dan hasil belajar kognitif siswa. Data tentang keterlaksanaan pembelajaran dapat dilihat pada Tabel 1, sedangkan hasil belajar kognitif siswa dapat dilihat pada Tabel 2. Tabel 1. Hasil kegiatan pembelajaran dan hasil belajar kognitif pada siklus I

\begin{tabular}{lcclc}
\hline \multirow{2}{*}{ Kegiatan } & \multicolumn{2}{c}{ Kegiatan pembelajaran } & \multicolumn{2}{c}{ Hasil belajar kognitif } \\
\cline { 2 - 5 } & Pertemuan 1 & Pertemuan 2 & $\begin{array}{l}\text { Banyaknya siswa } \\
\text { yang ikut evaluasi }\end{array}$ & 13 \\
\hline $\begin{array}{l}\text { Jumlah langkah yang } \\
\text { harus dilaksanakan }\end{array}$ & 11 & 18 & Nilai tertinggi & 77.5 \\
$\begin{array}{l}\text { Jumlah langkah yang } \\
\text { terlaksana }\end{array}$ & 7 & 16 & Nilai terendah & 35 \\
$\begin{array}{l}\text { Kegiatan awal } \\
\text { Kegiatan inti }\end{array}$ & 3 & 5 & $\begin{array}{l}\text { Rata-rata } \\
\text { Jumlah siswa yang }\end{array}$ & 69 \\
Penutup & 3 & 9 & $\begin{array}{l}\text { Juntas } \\
\text { tidak tuntas }\end{array}$ & 7 \\
Prosentase $(\%)$ & 1 & 2 & $\begin{array}{l}\text { Ketuntasan } \\
\text { klasikal }\end{array}$ & $46 \%$ \\
Kategori & 63.63 & 88.88 & Kategori & Tidak tuntas \\
\hline
\end{tabular}

Tabel 2. Hasil kegiatan pembelajaran dan hasil belajar kognitif pada siklus II

\begin{tabular}{ccclc}
\hline \multirow{2}{*}{ Kegiatan } & \multicolumn{2}{c}{ Kegiatan pembelajaran } & \multicolumn{2}{c}{ Hasil belajar kognitif } \\
\cline { 2 - 5 } & Pertemuan 1 & Pertemuan 2 & $\begin{array}{l}\text { Banyaknya siswa } \\
\text { yang ikut evaluasi }\end{array}$ & 13 \\
\hline $\begin{array}{l}\text { Jumlah langkah yang } \\
\text { harus dilaksanakan }\end{array}$ & 11 & 17 & Nilai tertinggi & 82.5 \\
\hline
\end{tabular}




\begin{tabular}{lcclc}
\hline \multirow{2}{*}{ Kegiatan } & \multicolumn{2}{c}{ Kegiatan pembelajaran } & \multicolumn{2}{c}{ Hasil belajar kognitif } \\
\cline { 2 - 5 } & Pertemuan 1 & Pertemuan 2 & $\begin{array}{l}\text { Banyaknya siswa } \\
\text { yang ikut evaluasi }\end{array}$ & 13 \\
\hline $\begin{array}{l}\text { Jumlah langkah yang } \\
\text { terlaksana }\end{array}$ & 8 & 16 & Nilai terendah & 55 \\
Kegiatan awal & 5 & 5 & $\begin{array}{l}\text { Rata-rata } \\
\text { Jumlah siswa yang }\end{array}$ & 72 \\
Kegiatan inti & 3 & 9 & $\begin{array}{l}\text { tuntas } \\
\text { Jumlah siswa yang } \\
\text { tidak tuntas }\end{array}$ & 3 \\
Penutup & 1 & 3 & $\begin{array}{l}\text { Ketuntasan } \\
\text { klasikal } \\
\text { Kategori }\end{array}$ & $76 \%$ \\
Prosentase (\%) & 72.72 & 94.44 & Tuntas \\
Kategori & Baik & Sangat baik & Kategori
\end{tabular}

Pada tahap perencanaan, semua keperluan pada tahap tindakan ditentukan, seperti menyusun skenario pembelajaran, menyusun alat evaluasi, menyusun lembar observasi, dan menentukan observernya, menyusun dan menyiapkan lembar kegiatan siswa (LKS), serta memilih atau menentukan kebutuhan-kebutuhan pendukung, seperti menyiapkan alat dan bahan praktikum. Jika tahap perencanaan selesai dilakukan, kemudian masuk pada tahap tindakan atau tahap aksi. Pada tahap tindakan, blueprint yang telah disusun pada tahap perencanaan diimplementasikan, atau dengan lain kata, tahap tindakan merupakan cerminan dari tahap perencanaan.

Proses perekaman atau pengumpulan mengenai kegiatan atau proses pembelajaran yang berlangsung dilakukan pada tahap tindakan, sedangkan tahap evaluasinya dilakukan pada tahap evaluasi, termasuk melakukan evaluasi hasil belajar kognitif siswa terhadap materi yang telah diajarkan pada tahap tindakan. Hasil observasi mengenai keterlaksanaan pembelajaran dan hasil belajar kognitif siswa dapat dilihat pada Tabel 1. Memperhatikan hasil penelitian seperti yang terlihat pada Tabel 1 di atas, diketahui bahwa pada siklus I, pertemuan 1, jumlah langkah pembelajaran yang terlaksana sebanyak 7 langkah (63.63), berkategori baik, sedangkan pada pertemuan ke 2, jumlah langkah pembelajaran yang terlaksana sebanyak 16 langkah (88.88), berkategori sangat baik, dan hasil belajar kognitif siswa secara klasikal dinyatakan tidak tuntas dengan prosentase sebesar $46 \%$.

Hasil yang diperoleh pada sikus I tersebu yang ditunjukkan Tabel 1, dipengarui oleh beberapa hal, yakni faktor kesiapan (readiness), seperti kesepian peneliti dalam menerapkan skenario pembelajaran kooperatif tipe GI, serta kesiapan siswa untuk mengikuti proses pembelajaran sesuai dengan proses pembelajaran GI, sehingga kondisi kesiapan ini, menyebabkan banyak waktu yang tersita untuk menyampaikan atau mendiskusikan materi pembelajaran. Untuk mengatasi kekuarangan atau permasalahan pada siklus I tersebut, berdasarkan hasil refleksi sangat perlu untuk dilakukan perbaikan dalam proses pembelajaran harus direncanakan dengan baik, karena tanpa perencanaan yang baik, mustahil target pembelajaran bisa tercapai secara maksimal (Muslich, 2007). Dalam proses pembelajaran, khusunya pada fase awal (pendahuluan) diinformasikan kepada siswa mengenai model kooperatif tipe GI yang digunakan, serta kegiatan-kegiatan yang akan dilakukan siswa, sehingga siswa lebih siap, lebih mudah berinteraksi mengikuti proses pembelajaran sesuai dengan skenario pembelajaran kooperatif 
tipe GI, serta model pembelajaran kooperatif tipe GI harus lebih akomodatif, dalam artian harus lebih menekankan pada proses aktif siswa, dan memberikan penguatan (reinforcement) kepada siswa. Hasil refleksi yang dilakukan dimanifestasikan pada tahap perencanaan dan tindakan.

Berdasarkan hasil siklus II seperti yang terlihat pada Tabel 2, diketahui bahwa, jumlah langkah yang terlaksana pada pertemuan pertama sebanyak 8 langkah, atau sebesar 72.72\% (berkategori baik), sedangkan pada pertemuan ke 2, sebanyak 16 langkah pembelajaran yang terlaksana, atau sebesar 94.44\% (berkategori sangat baik), dan hasil belajar kognitif siswa dinyatakan tuntas secara klasikal dengan prosesntase sebesar $76 \%$. Hasil siklus II dapat dinyatakan berhasil, dan hasil ini (siklus II) sangat tidak terlepas dari kerjasama yang baik, baik antara peneliti dan observer, maupun antara peneliti dan siswa, atau dengan lain kata, proses pembelajaran pada siklus II benar-benar mengimplementasikan rekomendasi hasil refleksi siklus I. Sriwahyuningsih dkk (2018) menyatakan pembelajaran kooperatif dapat menuntut siswa belajar bertanggung jawab, menumbuhkembangkan sikap dan perilaku demokratis serta peran aktif dalam proses pembelajaran.

\section{KESIMPULAN}

Berdasarkan hasil penelitian dan pembahasan dapat disimpulkan bahwa penerapan model pembelajaran Group Investigation dapat meningkatkan hasil belajar kognitif siswa kelas X MIA 2 SMAS NW Mataram pada pelajaran IPA Biologi Tahun Pelajaran 2018/2019.

\section{SARAN}

Meskipun penelitian ini dinyatakan berhasil, akan tetapi hasil yang dicapai masih berada dalam kisaran normal, yakni sebesar 76\%, dan karena keterbatasan waktu, sehingga peelitian ini peneliti anggap cukup meskipun hanya sampai pada KKM 76\%. Oleh karena itu, untuk penelitian selanjutnya, baik yang berkeinginan untuk mengkaji tema pembelajaran kooperatif tipe GI maupun tipe yang lainnya menggunakan PTK, disarankan untuk menggunakan siklus yang lebih banyak, sehingga diperoleh hasil yang melebihi standar KKM (75\%), atau mencapai maksimal.

\section{DAFTAR PUSTAKA}

AL-Jaziah. (2013). Penerapan Model Pembelajaran Kooperatif Tipe Pertandingan Kelompok (Team Quiz) Untuk Meningkatkan Aktifitas dan hasil belajar siswa kelas VII MTs. Hidayatul Athfal Rebila Tahun Pelajaran 2012/2013. Skripsi diterbitkan di IKIP Mataram.

Ama, F.T \& Sartati, S.B. (2018). Meningkatkan Hasil Belajar Siswa dengan Model Snowball Throwing pada Pokok Bahasan Penyelesaian Pertidaksamaan Kuadrat. Jurnal Penelitian dan Pengkajian Ilmu Pendidikan: e-Saintika, 1(2), 73-80.

Anderson, L.W. \& Krathwohl, D.R. (2001). Kerangka Landasan untuk Pembelajaran, Pengajaran, dan Asesmen (Terjemahan). Yogyakarta: Pustaka Pelajar.

Arikunto, S. (2012). Penelitian Tindakan Kelas. Jakarta. Bumi Aksara.

Hamdayama. (2016). Metodologi pengajaran. Jakarta: Bumi Aksara. 
Khotimah, H., Sumiyati \& Nurjannah. (2017). Pengaruh Teknik Pembelajaran Listening Team Terhadap Hasil Belajar IPS Siswa. Jurnal Penelitian dan Pengkajian Ilmu Pendidikan: e-Saintika, 1(1), 1-10.

Lubis, J., A \& Lubis, F., A. (2017). Peningkatan Hasil Belajar Siswa Melalui Penerapan Model Pembelajaran Kooperatif Tipe Group Investigation (GI) di Kelas X MA Muhammadiyah 06 Kotanopan. Jurnal Penelitian Tindakan Kelas dan Pengembangan Pembelajaran, 1(1), 1-7.

Muslich, M. 2007. KTSP. Pembelajaran Berbasis Kompetensi dan Kontekstual. Panduan Bagi Guru. Kepala Sekolah dan Pengawas Sekolah. Jakarta: Bumi Aksara.

Pour, D., N., Herayanti, L., \& Sukroyanti, B., A. (2018). Pengaruh Model Pembelajaran Talking Stick terhadap Keaktifan Belajar Siswa. Jurnal Penelitian dan Pengkajian Ilmu Pendidikan: e-Saintika, 2(1), 36-40.

Prayogi, S., \& Asy'ari, M. (2013). Implementasi model PBL (Problem Based Learning) untuk meningkatkan hasil belajar dan kemampuan berpikir kritis siswa. Prisma Sains : Jurnal Pengkajian Ilmu dan Pembelajaran Matematika dan IPA IKIP Mataram, 1(1), 80-88. Retrieved from http://ojs.ikipmataram.ac.id/index.php/prismasains/article/view/521/485

Primarinda. (2012). Pengaruh Model Pembelajaran Kooperatif Group Investigation (GI) terhadap Ketrampilan Proses Sains dan Hasil Belajar Biologi Siswa Kelas X SMA 4 Surakarta. Surakarta: Fakultas Keguruan dan Ilmu Pendidikan Universitas Sebelas Maret Surakarta, Skripsi (Online), (http://biologi.fkip.uns.ac.id/wpcontent/uploads/2012/02/IKHAPRIMARINDA-K4308040.pdf, diakses pada tanggal 01 April 2015).

Purwanto. (2010). Prinsip-prinsip dan Teknik Evaluasi Pengajaran. Bandung: Remaja Rosdakarya.

Sanjaya, W. (2009). Kurikulum dan Pembelajaran: Teori dan Praktik Pengembangan Kurikulum Tingkat Satuan Pendidikan (KTSP). Jakarta: Kencana.

Sari, N., M \& Eurika, N. (2016). Penerapan Model Pembelajaran Group Investigation Untuk Meningkatkan Hasil Belajar Siswa di Kelas XI PHP 2 SMK Negeri 5 Jember. Jurnal Biologi dan Pembelajaran Biologi, 1(1), 29-41.

Sriwahyuningsih, D., Ahzan, S., \& Habiburrahman, L. (2018). Pengaruh Model Pembelajaran Koperatif Tipe Make A Macth dengan Permainan Rangking One Physical Terhadap Motivasi dan Hasil Belajar Siswa. Jurnal Penelitian dan Pengkajian Ilmu Pendidikan: e-Saintika, 2(1), 29-35. doi:https:// doi.org/10.36312/e-saintika.v2i1.109

Sudjana. (2010). Penilaian Hasil Proses Belajar-Mengajar. Bandung: Remaja Rosdakarya.

Sumiyati., Nurjannah., \& Khotimah, H. (2017). Perbandingan Hasil Belajar IPS Terpadu Model Pembelajaran Kooperatif Tipe Two Stay-Two Stray Dengan Metode Ceramah. Jurnal Penelitian dan Pengkajian Ilmu Pendidikan: e-Saintika, $1(1), 33-44$.

Warsito. (2012). Metode Pembelajaran. Jakarta: Rineka Cipta. 